\title{
Rare Association of Trisomy 13 with Ectrodactyly and Congenital Diaphragmatic Hernia
}

\author{
Wafaa Alrawi $^{1}$, Ashraf Abuobayda ${ }^{1}$, Nabil Elmansoury ${ }^{1}$, Abhijeet Lonikar ${ }^{1}$, Anas \\ Alshorman ${ }^{1}$, and Hasansaheb Maldar ${ }^{1}$ \\ ${ }^{1}$ Abu Dhabi Health Services Co
}

February 19, 2021

\begin{abstract}
In 2020, we had reported one of the few cases of trisomy 13 with ectrodactyly, a rare form of limb deformity. Herein, we report another newborn who suffered from trisomy 13 and ectrodactyly. The patient also possessed another unusual manifestation of trisomy 13 , congenital diaphragmatic hernia, a life- threatening pathology.
\end{abstract}

\section{Rare Association of Trisomy 13 with Ectrodactyly and Congenital Diaphragmatic Hernia}

Wafaa N Al Rawi, Ashraf N Abuobayda, Nabil S Elmansoury, Abhijeet S Lonikar, Anas A Alshorman, Hasansaheb D Maldar

\section{Correspondence}

Wafaa N Al Rawi

Neonatologist,

Department of Pediatrics,

SSMC Hospital, SEHA, Abu Dhabi, United Arab Emirates.

Email:wafarawi@yahoo.co.uk

Institutional affiliations: Department of Pediatrics, SSMC Hospital, Abu Dhabi, United Arab Emirates

Sheikh Shahbout Medical City in partnership with MAYOCLINIC

Funding Information; None

\section{Abstract:}

In 2020, we had reported one of the few cases of trisomy 13 with ectrodactyly, a rare form of limb deformity. Herein, we report another newborn who suffered from trisomy 13 and ectrodactyly. The patient also possessed another unusual manifestation of trisomy 13, congenital diaphragmatic hernia, a life- threatening pathology.

Keywords: ectrodactyly, trisomy 13, congenital diaphragmatic hernia, split-hand/split-foot malformation

\section{Abbreviation:}

CDH: congenital diaphragmatic hernia

\section{Introduction}


Trisomy 13 or Patau syndrome, (Patau et al., 1960), is characterized by a wide range of anomalies including complex heart and brain malformations. Resuscitation at birth is abandoned owing to the poor prognosis and associated lethal anomalies, the median survival of trisomy 13 patients is only less than few months.

The association between trisomy 13 and ectrodactyly, a split-hand/split-foot malformation caused by an abnormal median cleft of the hand or foot giving a lobster claw-like appearance to the hand and/or foot, was first described by Urioste et al. (1994). To the best of our knowledge, only three cases of ectrodactyly in patients with trisomy 13 have been reported to date, including the one previously published by our group (Urioste et al., 1994; Feben et al., 2015; Al Rawi et al., 2020). Here, we report another case of ectrodactyly in a patient with trisomy 13 . The patient also presented with congenital diaphragmatic hernia (CDH), a serious malformation which occurs due to the developmental defect in the diaphragm allowing the abdominal viscera to herniate into the chest, resulting in lung hypoplasia and pulmonary hypertension, thus associated with significant risk of morbidity and mortality. $\mathrm{CDH}$, as with ectrodactyly, has been infrequently described in patients with trisomy 13 .

\section{Case Presentation}

A male newborn weighing approximately 2,400 grams was delivered spontaneously at 36 weeks' gestation as the first child of nonconsanguineous parents. At 29 to 30 weeks' gestation, fetal ultrasonography detected a left $\mathrm{CDH}$, bilateral cleft lip and palate, and bilateral, echogenic, and enlarged kidneys. Parents declined amniocentesis. Immediately after delivery, the patient was intubated and ventilated. His Apgar score was 4 at one minute and 7 at five minutes.

Physical examination revealed multiple associated malformations such as microphthalmia, bilateral cleft lip and palate, deformed left ear, scaphoid abdomen, micropenis, bilateral cryptorchidism, rocker-bottom feet, and right-hand ectrodactyly with four fingers (oligodactyly), and deep medial cleft giving the appearance of lobster claws (Figures 1-6). Left $\mathrm{CDH}$ and bilateral hydroureter and hydronephrosis were confirmed by radiography. Brain ultrasonography results revealed cerebellar hypoplasia and hypogenesis of the corpus callosum, and echocardiography results showed mild tricuspid regurgitation and a deformed/calcified tricuspid valve. Trisomy was suspected, and the diagnosis of non-disjunction trisomy 13 was confirmed by genetic testing (karyotype 47,XY,+13).

The infant required high-frequency oscillator ventilation and inhaled nitric oxide for severe respiratory failure, refractory hypoxia, and inotropic support. He deteriorated with no response and died on his fourth day of life.

\section{Discussion}

The extent and severity of trisomy 13, a common aneuploidy, depend on the specific location of the trisomy in chromosome 13, as well as the percentage of abnormal cells. Affected infants usually present with the profound mental retardation, microcephaly, microphthalmia, cleft lip, cleft palate, hypertelorism, malformed ears, abnormalities of the central nervous system, renal malformations, congenital cardiac defects, capillary hemangiomas (most frequently on the center of the forehead), and limb malformation. Males may also be affected by cryptorchidism. In addition, limb malformations, including polydactyly, flexion and possible overlapping of fingers, and prominent heels of the feet, are common in infants with trisomy 13 syndrome. However, Ectrodactyly, a deformity affecting the central rays of the hands and/or feet, and occurs as an isolated entity or as part of a syndrome, is a rare presentation in infants with trisomy 13. Indeed, there have been only a few reported cases.

Our patient also possessed congenital diaphragmatic hernia, another rare finding in patients with trisomy 13. CDH is life- threatening pathology in infants and can be a major cause of death. It can be either an isolated anomaly or associated with other abnormalities, such as major structural malformations, chromosomal abnormalities, and/or single gene disorders. Severe anomalies associated with CDH may influence diagnosis, treatment, and survival. In our patient, an antenatal scan detected left $\mathrm{CDH}$ as an anomaly. Although a prenatal genetic diagnosis of trisomy would have aided decision-making and allowed for the creation of a 
treatment plan, it was not performed. Upon birth, the presence of multiple congenital anomalies combined with $\mathrm{CDH}$ suggested a complex chromosomal diagnosis, which was confirmed by postnatal karyotyping as trisomy 13. This result deferred the decision of surgical management as the prognosis for CDH is poor in an abnormal chromosomal microarray case.

\section{Conclusion}

This case study reports a rare case of a patient with Trisomy 13 that presented both ectrodactyly and $\mathrm{CDH}$, which are very rarely presented with Trisomy 13. Our findings expand the known clinical features of trisomy 13 by including ectrodactyly as a possible trisomy 13-associated limb malformation. In addition, $\mathrm{CDH}$ is an unusual trisomy 13 manifestation for which creating a treatment plan is difficult without a confirmed diagnosis. Thus, we highlight the importance of performing antenatal genetic tests to establish more specific treatment strategies and offering genetic counseling and parental support for cases in which multiple congenital defects have been detected in utero .

\section{Acknowledgments}

We are grateful to the patient's family for participating in this study. We also thank Dr. Iftikhar Suleman and Dr. Muna Al Shehhi for their support as pediatrics surgeons.

\section{References}

Al Rawi, W., Mustafa, K., Abuobayda, A., \& Obaid, L. (2000). Rare presentation of ectrodactyly in trisomy 13. Journal of Clinical Neonatology, 9 , 143-145.

Duijf, P. H., van Bokhoven, H., \& Brunner, H. G. (2003). Pathogenesis of split-hand/split-foot malformation. Human Molecular Genetics ,12 Spec No 1, R51-R60. doi:10.1093/hmg/ddg090

Feben, C., Kromberg, J., \& Krause, A. (2015). An unusual case of trisomy. South African Journal of Child Health 9, 13 , 61-62.

Jain, A., Kumar, P., Jindal, A., \& Sarin Y. K. (2015). Congenital diaphragmatic hernia in a case of Patau syndrome: A Rare Association. Journal of Neonatal Surgery , 4, 20.

Martínez-Frías, M. L., Villa, A., de Pablo, R. A., Ayala, A., Calvo, M. J., Bermejo, E., \& Rodríguez, L. (2000). Limb deficiencies in infants with trisomy 13. American Journal of Medical Genetics , 93 , 339-341. doi:10.1002/1096-8628(20000814)93:4<339::aid-ajmg15>3.0.co;2-r

Patau, K., Smith, D. W., Therman, E., Inhorn, S. L., \& Wagner, H. P. (1960). Multiple congenital anomaly caused by an extra autosome.Lancet , 1 , 790-793. doi:10.1016/s0140-6736(60)90676-0

Sahin, S., Kutman, K. H., Bozkurt, O., Canpolat, F. E., Uras, N., Oguz, S. S., . . . Dilmen, U. (2015). A trisomy 13 case presenting with congenital diaphragmatic hernia and microphthalmia. Genetic Counseling , $26,263-265$.

Urioste, M., Martinez-Frias, M. L., \& Aparicio, P. (1994). Ectrodactyly in trisomy 13 syndrome. American Journal of Medical Genetics ,53 , 390-392. doi:10.1002/ajmg.1320530422

\section{Figure Legends}

Figure 1: Bilateral microphthalmia, bilateral cleft lip and palate, and malformed ears

Figure 2: Malformed and apparently low-set ears

Figure 3: Bilateral cryptorchidism

Figure 4: Rocker bottom feet

Figure 5: Right split lobster claw-like hands

Figure 6: The right hand has four fingers and deep medial cleft 


\section{Hosted file}

Figure_1.docx available at https://authorea.com/users/396692/articles/509809-rareassociation-of-trisomy-13-with-ectrodactyly-and-congenital-diaphragmatic-hernia

Hosted file

Figure_2.docx available at https://authorea.com/users/396692/articles/509809-rareassociation-of-trisomy-13-with-ectrodactyly-and-congenital-diaphragmatic-hernia

\section{Hosted file}

Figure_3.docx available at https://authorea.com/users/396692/articles/509809-rareassociation-of-trisomy-13-with-ectrodactyly-and-congenital-diaphragmatic-hernia

\section{Hosted file}

Figure_4.docx available at https://authorea.com/users/396692/articles/509809-rareassociation-of-trisomy-13-with-ectrodactyly-and-congenital-diaphragmatic-hernia

Hosted file

Figure_5.docx available at https://authorea.com/users/396692/articles/509809-rareassociation-of-trisomy-13-with-ectrodactyly-and-congenital-diaphragmatic-hernia

\section{Hosted file}

Figure_6.docx available at https://authorea.com/users/396692/articles/509809-rareassociation-of-trisomy-13-with-ectrodactyly-and-congenital-diaphragmatic-hernia 